\title{
European Liaisons? A Study on European bi-national Marriages in Belgium
}

\author{
Suzana Koelet ${ }^{1}$ and Helga A.G. de Valk ${ }^{1,2}$ \\ ${ }^{1}$ Vrije Universiteit Brussel, Interface Demography, Brussels, Belgium \\ ${ }^{2}$ Netherlands Interdisciplinary Demographic Institute, The Hague, The Netherlands
}

\section{ABSTRACT}

European bi-national marriages as a special case of interethnic unions have received relatively little attention in research. Existing studies on interethnic marriage mainly orient on union formation among non-western migrants and in particular intermarriages between the majority group and non-western migrants, which are often perceived as indicators for integration. European intermarriages can nonetheless be of similar interest from the perspective of European integration and identity formation. In this article, we first study the patterns and trends in bi-national European marriages in Belgium. Second, we analyse the diversity in bi-nationally married couples, and third, we pinpoint the characteristics of these European couples. We use the Belgian marriage register data from 1989 to 2010 as well as the census data from 2001. Our findings show that European bi-national marriages are still relatively limited in Belgium and that their numbers (and proportion) have remained constant over time over the past decade. There is nevertheless variety in the level of intermarriage among different nationality groups. Our analyses point to six different types of European bi-national marriages with different characteristics of the partners and their place of residence. Copyright (C) 2013 John Wiley \& Sons, Ltd.

\section{Accepted 13 December 2012}

Keywords: intermarriage, European mobility, European integration, bi-national marriages, free movers

*Correspondence to: Koelet, Suzana, Interface Demography, Vrije Universiteit Brussel, Brussel, Belgium.

E-mail: skoelet@vub.ac.be

\section{INTRODUCTION}

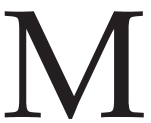
ixed marriages between partners of a different ethnicity or nationality have often been used as an indicator of social integration and fading group boundaries (cf. Barth, 1969; Kalmijn, 1998; Qian and Lichter 2007; Kalmijn and Van Tubergen, 2010). As a consequence, the bulk of intermarriage literature in Europe focuses on the marriages between partners from non-western minority groups with the native population (for exceptions, see Behtoui, 2010; Celikaksoy et al., 2010; Koelet et al., 2012). Discussions on Europe's social integration recently started to attract attention to European bi-national marriages (Delhey, 2004; Hooghe and Marks, 2004; Delanty, 2005; Bach et al., 2006; Diez Medrano, 2008; European Commission, 2011; Lanzieri, 2011). In this literature, European intermarriage (cf. Lauth, 2002; Braun and Recchi, 2008) is often considered as both an indicator and motor of European integration.

In this article, we focus on Belgium and shed light on the trends and patterns of these marriages as well as the characteristics of the partners involved. First, what is the prevalence of European intermarriage in Belgium (i.e. marriages conducted between two partners of a different European nationality) and what are the trends in these marriages over time? Second, we question which EU nationals Belgians mainly marry to by also looking at the propensities for Belgian European intermarriages. Finally, we explore the level of diversity among the group of European bi-national married by origin, individual, and couple characteristics. We use the Belgian marriage register and census data and define European bi-national marriages as marriages between partners of a different European nationality at the time of marriage. This definition encompasses both crossborder marriages and marriages between two 
different European nationals living already in the same country.

Belgium is an interesting case for studying European bi-national marriages. Several large EU neighbours surround the country and share one of the three official languages spoken in Belgium. Its capital, Brussels, is the informal capital of the European Union and attracts many Europeans who come to work in European institutions and multinationals located in and around the city (Huysseune and Jans, 2008; Gatti, 2009). The Belgian foreign population is by consequence characterised by an overrepresentation of Europeans and in particular EU citizens (CGKR, 2009). In 2010, more than two-thirds of all foreigners living in Belgium were EU citizens as compared with an average of around 38\% for all EU27 countries (CGKR, 2012). It is argued that the different regions and linguistic communities in Belgium prevent the country from being a national society with a welldefined single dominant identity (Favell, 2001, 2008). In the multilingual Brussels, Europeans may be able to integrate as in a denationalised space (less national and more cosmopolitan) providing opportunities for the development of new identities. In this paper, we look at the extent to which this opportunity structure is reflected in European binational marriages by studying trends in and determinants of these relationships.

\section{BI-NATIONAL MARRIAGES IN A EUROPE WITHOUT FRONTIERS: PREVALENCE AND TRENDS}

Union formation literature emphasises the importance of the opportunities to meet and interact socially on the chances for members of different groups to intermarry (Blau, 1994; Kalmijn, 1998; Johnson and Jacobson, 2005). The free mobility realised within the European Union potentially allows many more and increasing meeting opportunities among EU citizens. The first steps toward a single market in which goods, capital, services, and people would be able to move freely were taken in 1957, when Belgium and five other European countries signed the Treaty of Rome establishing the European Economic Community, forerunner of the European Union. The initiative was mainly economically motivated, although it also aimed to achieve a closer union of citizens and Member States. Integrating the market was merely a means to this end (O'Dowd, 2003). The
Single European Act of 1986 set the framework for abolishment of the last barriers and obstacles to the Single Market, and the Treaty of Maastricht in 1993 paved the way for a European Monetary Union and an integrated market.

However, this 'Europe without frontiers' did not immediately yield a high degree of internal European mobility. Even today, internal migration of EU citizens in Europe is relatively limited (Threlfall, 2003). Only four percent of the EU population (EU27) has ever moved to another European country (Bonin et al., 2008, 4), and less than half a percent of Europeans at working age migrate across European borders (Boeri et al., 2002; Bonin et al., 2008). The number of Europeans that live in another European country has nevertheless increased during past decades and so has the relative proportion of European compared with non-European immigrants (Vasileva, 2009). Between 2001 and 2010, the proportion of foreigners living in one of the EU27 countries increased from $4.5 \%$ to $6.5 \%$, whereas the proportion of Europeans among them increased from 34\% to 38\% (Eurostat 2011). The face of international migration in Europe seems to be changing as Europeans take on an ever-larger share in recent immigration flows to various EU member states (Salt and Almeida 2006). The recent increase in immigration in Belgium and the Netherlands is likewise mainly due to the growing number of European immigrants (de Valk et al., 2011).

The European mobility trends recently observed lead to new contacts and links raising the odds of meeting someone of another European nationality or coming into contact with other EU nationals on a daily basis. In the intermarriage literature, Blau and his colleagues identify a number of structural characteristics facilitating social contact (Blau, 1977, 1994; Blau and Schwartz, 1984). The degree of heterogeneity in the population is one of the factors found to correlate positively with the level of exogamous unions among a population (Blau and Schwartz, 1984). The European integration project may thus lead to Europeanisation of the marriage market. Other influences expand the potential for partners of different nationalities to meet even further. In a world marked by international connections via internet, cheap airline tickets, and widespread telephone networks, social networks may become ever more fluid and international. In line with this, 
some recent studies suggest that the local context is losing importance for the marriage market (cf. Niedomysl et al., 2010; Glowsky, 2011) and one could expect marriages across borders to become more important.

Some studies in the US (Kalmijn, 1998: 410) and the UK (Muttarak, 2009) indeed show that interethnic marriages are increasing. For the Netherlands, intermarriage patterns in turn seem to be relatively stable, although there is large variation between origin groups (de Valk et al., 2004). The few analyses focusing explicitly on European bi-national marriages in France and Portugal seem to suggest that this type of intermarriage is on the increase (Prioux, 2004; Gaspar, 2008). In Belgium, quantitative data on size and trends are scarce, and most work includes qualitative studies on interethnic unions with those of Moroccan and Turkish descent (Lievens, 1998, 1999; Yalçin et al., 2006; Lodewyckx et al., 2006; Timmerman et al. 2009; D'Haenens 1995; Reniers and Lievens, 1997; Colpaert, 2000). We explore both prevalence and time trends of binational marriages in Belgium, which are guided by a first set of expectations based on the mobility and meeting opportunities of partners in Europe. Given the relatively limited European mobility, we expect that marriages between two partners of a different European nationality are still rather uncommon and refer to a minor proportion of all marriages. At the same time, we expect that this proportion in bi-national European marriage has increased in the past decade.

\section{NATIONAL COMPOSITION OF BI-NATIONAL MARRIAGES}

Although increased mobility and interconnectivity within the European Union may facilitate European bi-national marriages, this may not be sufficient. Studies on intermarriage have argued and demonstrated the preference for marrying a partner who is as similar as possible on a range of characteristics (Kalmijn, 1998: 399; Kalmijn 1998; van Tubergen and Maas, 2007). Earlier research indicates that for a long-term relationship to develop, it is important that partners accept each other as socially equal or as belonging to the in-group' (Qian and Lichter, 2007). Only then can barriers in social interaction and intimacy be overcome and diminished.
The influence of social proximity of other European nationalities is therefore crucial for understanding the mechanisms behind European intermarriages. The geographical proximity of neighbouring countries can moreover increase social proximity through exchange and meeting opportunities. In line with this, Offe (2000: 78) indicates that Europeans do not confer in-group status to all other Europeans but that this is typically limited for a select group of Europeans mainly those coming from neighbouring countries. Moreover, the integration of migrants in the host society will also have an effect on the blurring of group boundaries (Alba, 2005). As migrants reside longer and the second generation grows, opportunities for interaction and social acceptance rise. This will, for example, apply to traditional labour migrants from Southern Europe (e.g. Italy, Spain, and Greece) in Belgium who have resided in the country already for half a century now. The same may hold for EU citizens from the old EU members states where more time has passed that allows for the blurring or fading of social boundaries than is the case for the citizens from the new EU member states.

Given the importance of these preferences in considering potential marriage partners mainly when they are equal, leads us to expect that there will be variation in the level to which bi-national marriages occur between Belgians and other EU nationals. In line with the theory on geographical and social proximity, as indicators for in-group preference, our second set of expectations is that bi-national marriages between a Belgian partner and an EU neighbouring country (the Netherlands, France, Germany, and Luxembourg) as well as a Belgian and Southern European national (as a result of fading social boundaries) are more common than is the case for other EU nationalities.

\section{TYPES OF COUPLES AND DIVERSITY}

Intermarriage literature has indicated that some characteristics of the individual and couple are likely to affect the chances of exogamy. It has shown the relevance of cultural distance for the chances of interethnic unions (Dribe and Lundh, 2008, 2012; Kalmijn and Van Tubergen 2010). Also, intra-European married couples are not a homogenous group and also for these marriages factors related to (cultural) distance indicated by, for 
example, origin, period of residence, and immigrant generation are potentially important. In an explorative paper on European intermarriage, Gaspar (2008: 20) links the diversity in intermarriages to migration background and migration motives distinguishing four types of EU migrants in relation to European bi-national marriage. In addition to the traditional labour migrants (e.g. from Portugal and Spain to France and Germany), the 'recent labour migrants' between new and old EU countries (e.g. from Poland to Germany and France; Romania to Spain and Portugal), and migrants from neighbouring countries (e.g. the Swedes and Finns; Portuguese and Spanish), she emphasises the emergence of a group of EU free movers taking advantage of the social-political options provided by the common market of the EU. In the literature on European transnationalism and mobility, most attention is also devoted to these 'free movers', sometimes also called 'Eurostars' (Favell, 2003, 2008). They are a privileged group of usually highly educated European immigrants, who come from the educated middle or upper class. Characteristic of these 'free movers' is that their mobility is not so much motivated by economic necessity but that it is free and for personal or professional reasons (Lindenfeld and Varro, 2008). They migrate in favourable circumstances, and also, favourable circumstances usually await them after migration. We expect to find each of the four types of EU migrants as distinguished by Gaspar (2008) to be represented in the bi-national married population of Belgium. However, because the group of free movers is only a rather recent phenomenon in EU migration, we expect their share in the Belgian married population to be still relatively small.

Earlier work on partner choice has also indicated the relevance of a range of individual characteristics beyond nationality. The probability of mixed marriage increases for example with migrant generation (Khoo, 2004) and is more likely among higher educated than lower educated (see Kulczycki and Lobo, 2002; Chiswick and Houseworth, 2011). In addition, several studies show that intermarriage is gendered, but the direction of the relationship varies according to ethnic group (Celikaksoy et al., 2010; SánchezDomínguez et al., 2011). Here we take these individual characteristics into account and explore the diversity in characteristics among bi-national married couples in Belgium.

\section{DATA, DEFINITIONS, AND METHODS}

In this paper, we focus on both the newly contracted European bi-national marriages between 1989 and 2010 using the marriage register as well as the stock of European bi-national marriages based on the 2001 census (also referred to as SEE, 2001). The Belgian marriage register includes all marriages registered in Belgium per year and provides us with information on the incidence of mixed marriages, that is, all new (mixed) marriages in a given period of time (Kalmijn, 1998, 404). The data are suitable for exploring our first research questions on recent (patterns and trends in) European bi-national marriages. Because these data include little background information on the partners in these marriages, we turn to the Belgian census to study the diversity in European bi-national marriages by individual and couple characteristics. The census allows studying the prevalence of European bi-national marriages and their characteristics in the total married population residing in Belgium.

We define European bi-national marriages as marriages between partners with a different European nationality at the time of marriage. This definition potentially is sensitive to nationality changes as nationality at time of marriage might differ from nationality at time of birth. However, overall nationals of the European Union (EU15) decide to change their nationality much less often than non-EU nationals (CGKR, 2009). Furthermore, additional analysis (not shown here) on the nationality of married partners using the censuses of 1991 and 2001 shows that the large majority of married Belgians who had another EU nationality at birth have taken on the Belgian nationality only after their marriage $(78 \%)^{1}$, suggesting that bias is rather limited for our study population. In addition, one should be aware that the definition based on nationality implies that we also capture the second generation among EU nationals: those who have a foreign EU nationality but were born in Belgium (this is the case when both parents had a foreign nationality at time of birth of their child).

We use the marriage register to study recent binational marriages (2010) as well as the evolution of these marriages between 1989 and 2010. This time frame allows us to compare over time and disentangle between the situation before European unification in 1993 and during the period of consolidation of the European single market. We furthermore distinguish between EU12 
and EU27, because different countries entered the Union during the period under study.

Furthermore, the marriage register is used to study popular nationality combinations in European bi-national marriages, as well as the propensity for each European nationality to engage in a European bi-national marriage. For the latter, we use an adjusted intermarriage index based on the Intermarriage Index $\mathrm{Z}$ developed by Schoen (1988). The literature on intermarriage provides a large range of indicators to study endogamy and/or exogamy (for an overview, see Kalmijn 1998; Lanzieri, 2011). In a recent study, Lanzieri, (2011) compares a number of these indicators, all representing an index of exogamy and bounded to vary in a known interval. Schoen's Intermarriage Index $\mathrm{Z}$ is found to be one of the most robust indicators, which include simple transformations of well-known association indexes such as Yule's Q (comparable with odds ratios), Gray's V and index $\mathrm{H}$ (also Yule's phi). It is also the only indicator including information on the population and therefore independent from the age-sex-group composition of the population.

The Intermarriage Index $Z$ determines to what extent two groups are inclined to engage in an exogamous marriage. Schoen $(1988,214)$ proposes to use a simplified version ${ }^{2}, Z^{\prime}$, when specific information on age at migration is not available for the whole population. Our adapted version ${ }^{3}$, $\mathrm{Z}^{\prime}{ }^{\mathrm{a}}$, is no longer confined to two groups but measures the attraction between one specific European nationality and all other European nationalities. The index relates the bi-national marriages among men and women of a specific nationality between 2005 and 2010 to the number of men and women of this nationality present in the population on 1 January 2008. It takes a value between 0 (no intermarriage) and 1 (only intermarriage); a value of 0.5 indicates random partner selection in which nationality is of no relevance for partner choice.

To explore the composition and background characteristics of bi-national married couples, we turn to the census of 2001, which includes more individual and partner characteristics. These analyses include all bi-nationally married in the Belgian population. Nationality at time of birth will be used to best approximate the definition of European bi-national marriages used with the marriage register.

To describe the diversity in European binational marriages, a K-means cluster analysis is conducted. Information on the non-native European partner in the couple is used to discriminate between typical clusters of married persons. In case both partners are non-native, we use information on the most recently immigrated partner. Marriages between partners of the second generation are not included but a priori classified as an additional cluster. To distinguish the other clusters, we use four characteristics: (i) age at migration, (ii) years in Belgium at marriage, (iii) highest educational level, and (iv) closeness to the border of a neighbouring country. Descriptives for the measures are presented in Table 1.

Age at migration allows identifying not only the second generation but also those of the in-between generation (those who migrated at young age). Number of years in Belgium at the time of marriage is added to identify the couples that have married before (negative value) or after (positive value) migration to Belgium. Highest educational level allows for distinguishing

Table 1. Descriptives of the variables used in the cluster analysis ( $\mathrm{N}=120839$, marriages between partners of the second generation excluded).

\begin{tabular}{|c|c|c|c|c|c|}
\hline & $N$ & Minimum & Maximum & Mean & $\begin{array}{l}\text { Standard } \\
\text { deviation }\end{array}$ \\
\hline Age at migration (absolute years) & 106383 & 0 & 87 & 19.2 & 12.2 \\
\hline $\begin{array}{l}\text { Timing of marriage after migration } \\
\text { (in absolute years) }\end{array}$ & 106323 & -58 & 78 & 8.3 & 11.9 \\
\hline$<10 \mathrm{~km}$ from border municipality (1 yes) & 120839 & 0 & 1 & 0.2 & 0.4 \\
\hline $\begin{array}{l}\text { Highest educational level } \\
\text { (0 no qualification - } 13 \text { post-graduate } \\
\text { qualification) }\end{array}$ & 108534 & 0 & 13 & $\begin{array}{l}4 \text { (median) } \\
\text { Lower secondary } \\
\text { education }\end{array}$ & 6 \\
\hline
\end{tabular}

Source: SEE 2001 - ADSEI, own calculations. 
marriages of free movers from those of traditional or more recent low skilled migrants and consists of 13 ordinal categories, ranging from 'no qualification' (1) to a 'post-graduate qualification' (13). To identify the bi-national marriages resulting from the proximity to neighbouring countries, we calculate the distance from the current place of residence to the centre of the nearest municipality bordering a neighbouring country. Couples who live at a distance of less than $10 \mathrm{~km}$ of such a place and who are married to a partner with a nationality of a neighbouring country are distinguished from those living further away or who have no partner of such nationality. Because cluster analysis calculates distances between cases to identify homogeneous groups, and because variables are measured on a different scale, all variables are standardised.

The K-means cluster analysis requires a decision on the number of clusters beforehand. Because we could not assess the exact number of relevant clusters, the analysis was repeated several times with different number of clusters, until the clusters could neither be divided into smaller, more meaningful groups, nor aggregated without losing relevant information. ${ }^{4}$ This resulted in a six cluster solution. Two of these referred to marriages in which the most recently immigrated partner belonged to the in-between generation but who differed on educational level. Because this distinction is not relevant for our study, these two clusters were merged. This left us with five clusters, which were then complemented by the additional (sixth) cluster of European bi-national married of the second generation.

Before presenting our findings, it is relevant to provide some background on immigration to and migrants in Belgium. Immigration to Belgium has significantly increased over the past 60 years. Immigration was characterised by recruitment of labour migrants and colonial migrants in the 1950s and 1960s and has changed to asylum migration and family reunification in the decades thereafter. A typical feature of migration to Belgium has been the strong representation of European migrants in the flows. Since 1993, EU citizens can move free in the EU member states including Belgium. But it is only since the turn of the new century that European immigration to Belgium increased substantially, that is, after the accession of new member states to the EU in 2004 and 2007. Until very recent though (1 May
2009), citizens from these states were subjected to transitional measures limiting their free movement to Belgium ${ }^{5}$, and these measures are still in place for Romanians and Bulgarians today (until 31 December 2013). Nationals of EU15 countries take on the largest share in the recent migration flows to Belgium (especially the French (12.3\%) and Dutch $(8.8 \%))$, representing over a third of all recent immigrations. Nationals from the new member states represent another 19\% including substantial shares of Polish (9.9\%) and Romanians (6.1\%). Nationals from third (non-EU) countries make up the other half of recent immigrations (in particular, from Morocco (9.1\%) and Turkey (3.1\%)) (OECD 2011; CGKR 2012).

The foreign population of Belgium (2010) comprises just over one million people, or one out of 10 residents have a foreign nationality (Table 2). More than two-thirds of foreign nationals are European (EU27) and more than half have a nationality from a EU15 country. Also, four of the five largest foreign nationality groups are EU15 (not in Table) - Italian (16\%), French (13\%), Dutch $(13 \%)$, and Spanish $(4 \%)$ - whereas Moroccans rank fourth $(8 \%)$.

\section{EUROPEAN BI-NATIONAL MARRIAGES: PATTERNS AND TRENDS}

To answer our first research question, we focus on the patterns of bi-national European marriages using the marriage registers. For 2010, we find that one in six marriages include at least one partner of a foreign nationality (Table 3). Some of these marriages are uni-national (both partners have the same foreign nationality), but the vast majority

Table 2. Distribution of the Belgian population by nationality, 2010 (absolute and percentages).

\begin{tabular}{lrr}
\hline & $N$ & $\%$ \\
\hline Belgian nationals & 9839239 & 90 \\
Foreign nationals & 1057666 & 10 \\
EU-15 & 619792 & 59 \\
EU27 (excl. EU15) & 98363 & 9 \\
Other European countries & 84613 & 8 \\
Africa & 157592 & 15 \\
Asia & 66633 & 6 \\
America & 29615 & 3 \\
Oceania & 1058 & 0.1 \\
\hline
\end{tabular}

Source: CGKR 2012:28 - own calculations. 
is bi-national. The proportion of European binational marriages is as expected relatively modest: one in 16 marriages $(6.4 \%)$ and the large majority of them include partners from the 'old' EU12 countries.

A further analysis of the marriage records from 1989 to 2010 indicates that contrary to our expectation based on increased mobility and diminishing borders, the number and proportion of European bi-national marriages have not been rising over the past two decades (Figure 1). Trends are quite stable and slightly decreasing, in contrast to the trends in the total number of bi-national marriages including partners from outside the EU. The latter type of marriages has risen steeply between 1998 and 2004 but is on the decrease in recent years. For both the number and proportion of European bi-national marriages, we find that they have been declining. Between 1989 and 2010, their numbers have halved (from 4792 marriages in 1989 to 2698

Table 3. International and bi-national marriages in the total number of marriages registered in Belgium, 2010 (absolute and percentages).

\begin{tabular}{lcr}
\hline & $N$ & $\%$ \\
\hline $\begin{array}{l}\text { Total number of marriages registered } \\
\quad \text { in } 2010\end{array}$ & 42159 & 100 \\
$\begin{array}{l}\text { Marriages with at least one foreign } \\
\quad \text { partner }\end{array}$ & 7245 & 17.2 \\
Bi-national marriages & 6333 & 15.0 \\
European bi-national marriages (EU27) & 2698 & 6.4 \\
European bi-national marriages (EU12) & 2360 & 5.6 \\
& &
\end{tabular}

Source: Marriage Register 2010 - ADSEI, own adaptation. marriages in 2010), which is entirely attributable to the decline in marriages between partners from the 'old' EU countries (from 4.625 marriages to 2.360). The proportional trend indicates a more modest decline from $7.5 \%$ EU27 bi-national marriages in 1989 to $6.4 \%$ in 2010 . In any case, these data do not show a clear effect of the introduction of the Single Market in 1993 nor of the increased possibilities for mobility by the accession of the new EU member states in 2004.

When looking at the nationality composition of the European bi-national marriages contracted in the most recent period (2006-2010), we find that $93 \%$ include a Belgian partner (Table 4). Analyses for the individual separate years show a similar pattern. The Belgian-French, BelgianDutch, and Belgian-Italian couples account for as much as $62 \%$ of all European bi-national marriages registered between 2006 and 2010. The first two partner nationality combinations suggest a significant border effect. The cultural proximity between France and Wallonia and the Netherlands and Flanders, as well as the familiarity related to their geographical proximity and shared language, creates a significant affinity between these 'neighbours'. Apart from this, the substantial migration from Italy (one of the main labour migration streams in the 1950s and 1960s) is also reflected in the current levels of bi-national marriages in Belgium. The Belgian-German and Belgian-Spanish marriages rank next, although at a distance, and refer to the same border and history of migration effects. The Belgian-Polish marriages in turn result from more recent migration from Eastern Europe.

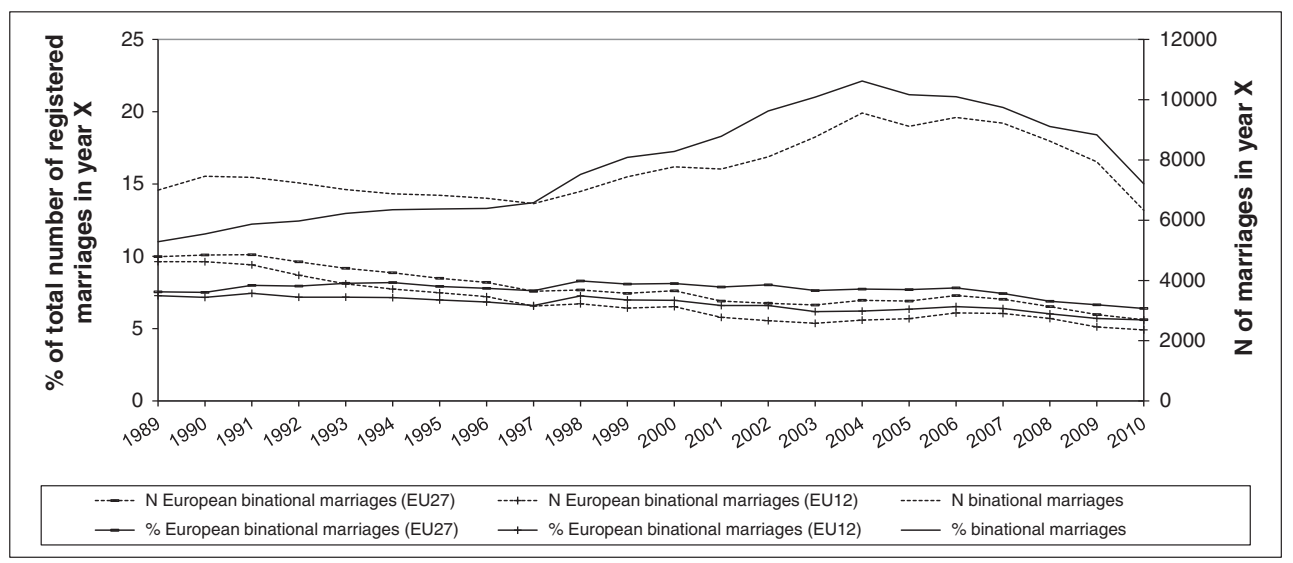

Figure 1. Trends in bi-national marriages in Belgium between 1989 and 2010. 
Table 4. Top six nationality combinations of European bi-national marriages (EU27) registered in Belgium 2006-2010, total and by sex (absolute and percentages).

\begin{tabular}{lrrrrrc}
\hline & $N$ & $\%$ & $\begin{array}{c}N \\
\text { with a } \\
\text { Belgian } \\
\text { man }\end{array}$ & $\begin{array}{c}\% \\
\text { with a } \\
\text { Belgian } \\
\text { man }\end{array}$ & $\begin{array}{c}N \\
\text { with a } \\
\text { Belgian } \\
\text { woman }\end{array}$ & $\begin{array}{c}\% \\
\text { with a } \\
\text { Belgian } \\
\text { woman }\end{array}$ \\
\hline $\begin{array}{l}\text { European bi-national marriages } \\
\quad \text { EU27) }\end{array}$ & 15572 & 100 & 7362 & 100 & 7166 & 100 \\
Belgian-French & 3973 & 25.5 & 1964 & 26.7 & 2009 & 28.0 \\
Belgian-Dutch & 3009 & 19.3 & 1299 & 17.6 & 1710 & 23.9 \\
Belgian-Italian & 2691 & 17.3 & 1060 & 14.4 & 1631 & 22.8 \\
Belgian-German & 862 & 5.5 & 483 & 6.6 & 379 & 5.3 \\
Belgian-Spanish & 794 & 5.1 & 394 & 5.4 & 400 & 5.6 \\
Belgian-Polish & 714 & 4.6 & 666 & 9.0 & 48 & 0.7 \\
\hline
\end{tabular}

Source: Marriage Register (2006-2010) - ADSEI, own adaptation.

Further analyses shows that the aforementioned patterns apply to both men and women even though the three dominant nationality combinations take on a larger share for women than for men ( $75 \%$ vs. $59 \%$, respectively). It is striking that Belgian men are much more likely to marry a Polish partner than is the case for Belgian women. Before joining the EU, migration from Poland to Belgium was highly gendered, and the majority of Polish women who migrated to Belgium did so to join their Belgian partner (Deschamps, 2005; CGKR, 2006). The gender balance among this group of migrants became gradually more balanced since entry into the Union in 2004, to the extent that there are currently more male than female Polish migrants arriving in Belgium (FOD WASO 2009, 62-63). However, these changes in gender composition of migration flows seem not yet reflected in marriages among Belgians and Poles.

To better understand the distribution of European bi-national marriages among the different nationalities, we calculated an Intermarriage Index (Table 5). This index (ranging from 0 full endogamy to 1 full exogamy) shows the propensity for a specific European nationality to marry a partner of a different European nationality (including a Belgian partner). Nearly all nationalities marry a partner of a different European nationality less often than in a situation of random partner selection (the index never reaches 0.5 , except for Luxembourgers). There are nevertheless relevant differences between nationality groups. The highest Intermarriage Indexes are found among Luxembourgers $\left(Z^{\prime}=0.50\right)$, British $\left(Z^{\prime a}=0.41\right)$ and
Germans $\left(Z^{\prime}=0.40\right)$. The French and Dutch are furthermore somewhat more likely to marry another European than the Italians, taking into account their presence in the population $\left(Z^{\prime a}\right.$ is 0.34 for French and Dutch and 0.32 for Italians). Immigrants from Eastern Europe are clearly less inclined to marry outside their own group than other European nationalities. The low intermarriage index for Portuguese also stands out. This group seems to isolate itself more than other groups on the European marriage market (together with a number of smaller nationalities for whom absolute numbers are low). This finding is consistent with the description of the Portuguese diaspora in Brussels as a closed community (Devos and Dams, 2010).

\section{EUROPEAN BI-NATIONAL MARRIED COUPLES: PREVALENCE AND DIVERSITY}

The second step in our analyses refers to the background characteristics of the European binational couples in the Belgian population based on the census data of 2001. In line with our expectations, we indeed find diversity in the binational married couples in Belgium. Cluster analyses discerned between six different types of European bi-national couples (Table 6). A first group, labelled the 'second generation', includes all native born couples with two partners of a different European nationality. This is the case for three out of 10 European bi-national couples. An additional group, representing two out of 10 couples, includes all couples with a foreign partner who moved to Belgium as a child (and 
Table 5. Intermarriage index per nationality (EU27), Belgium 2006-2010.

\begin{tabular}{|c|c|c|c|c|}
\hline & $\begin{array}{l}\text { Population on } 1 / 1 / \\
2008 \text { (age } 25 \text { to } 34 \text { ) }\end{array}$ & $\begin{array}{l}\text { Uni-national marriages } \\
\text { registered between } 2006 \\
\text { and } 2010\end{array}$ & $\begin{array}{l}\text { European bi-national marriages } \\
\text { registered between } 2006 \text { and } \\
2010 \text { (EU27) }\end{array}$ & $\begin{array}{c}\text { Age-specific } \\
\text { intermarriage index } \\
Z^{\prime a}(X-E U)\end{array}$ \\
\hline Belgians & 1176840 & 174027 & 14528 & 0.29 \\
\hline French & 26252 & 382 & 4320 & 0.34 \\
\hline Italians & 18929 & 442 & 3019 & 0.32 \\
\hline Dutch & 15423 & 887 & 3247 & 0.34 \\
\hline Polish & 10606 & 80 & 845 & 0.19 \\
\hline Spanish & 6141 & 58 & 962 & 0.33 \\
\hline Romanians & 5539 & 112 & 563 & 0.22 \\
\hline Portuguese & 5526 & 42 & 450 & 0.21 \\
\hline Germans & 4603 & 131 & 1,052 & 0.40 \\
\hline British & 3197 & 56 & 733 & 0.41 \\
\hline Bulgarians & 2229 & 62 & 205 & 0.20 \\
\hline Greeks & 1976 & 19 & 224 & 0.26 \\
\hline $\begin{array}{l}\text { Czechs/ } \\
\text { Slovaks }\end{array}$ & 1924 & 13 & 133 & 0.16 \\
\hline Hungarians & 1128 & 5 & 112 & 0.23 \\
\hline Swedish & 744 & 6 & 89 & 0.28 \\
\hline Irish & 590 & 11 & 118 & 0.37 \\
\hline Luxembourgers & 536 & 11 & 185 & 0.50 \\
\hline Danes & 521 & 5 & 75 & 0.33 \\
\hline Finns & 508 & 2 & 62 & 0.28 \\
\hline Lithuanians & 443 & 2 & 48 & 0.20 \\
\hline Austrian & 435 & 3 & 81 & 0.38 \\
\hline Latvians & 272 & 1 & 31 & 0.24 \\
\hline Estonians & 240 & 1 & 27 & 0.23 \\
\hline Slovenes & 226 & 2 & 15 & 0.17 \\
\hline Maltese & 95 & 1 & 13 & 0.31 \\
\hline Cypriots & 90 & 0 & 7 & 0.21 \\
\hline
\end{tabular}

Source: Marriage register (2006-2010) - ADSEI, own adaptation.

whose partner did not migrate at later age). This cluster is named the 'in-between generation'. The remaining $50 \%$ of couples (and four clusters) include at least one partner that migrated to Belgium after childhood. The third cluster (19\%) is couples where one partner came to Belgium as a migrant worker. The fourth cluster is those where the partner came to Belgium as a free mover $(13 \%)$. The fifth group refers to $12 \%$ of couples related to migration in border areas, and a final (sixth group) $4 \%$ refers to migration in later life (after marriage).

The vast majority of European bi-national couples in the population consist of a European and a Belgian partner (last column Table 6). They are largely dominating the second generation and in-between cluster as well as the group linked to neighbouring countries. Although European binational marriages without a Belgian partner are
Table 6. Typology of European bi-national marriages (EU27) and its distribution (absolute and percentages).

\begin{tabular}{lccrc}
\hline $\begin{array}{l}\text { Bi-national } \\
\text { marriages } \\
\text { linked to }\end{array}$ & $N$ & $\%$ & $\begin{array}{c}\% \\
\text { EU-EU }\end{array}$ & $\begin{array}{c}\% \\
\text { EU-Be }\end{array}$ \\
\hline $\begin{array}{l}\text { Second } \\
\text { generation }\end{array}$ & 56245 & 31.8 & 2.9 & 97.1 \\
$\begin{array}{l}\text { In-between } \\
\text { generation }\end{array}$ & 35505 & 20.0 & 7.1 & 92.9 \\
$\begin{array}{c}\text { First-generation } \\
\quad \text { labour }\end{array}$ & 33767 & 19.1 & 10.3 & 89.7 \\
$\quad$ migration & & & & \\
$\begin{array}{c}\text { Free movers } \\
\text { Neighbourship }\end{array}$ & 22928 & 12.9 & 14.9 & 85.1 \\
$\begin{array}{l}\text { Migration at } \\
\text { later age }\end{array}$ & 6939 & 12.3 & 3.4 & 96.6 \\
Total & 177084 & 100 & 7.6 & 92.4 \\
\hline
\end{tabular}

Source: SEE 2001 - ADSEI, own adaptation. 
a minority, overall they are better represented in particular among the cluster 'migration at later age' $(23 \%)$.

Table 7 provides a more detailed description of background characteristics of the European partner in the couple (in the case of European-Belgian couples) or of the most recently migrated partner (in the case of European-European couples) for each of the identified clusters. Typical for the partner in the 'second generation' and 'in-between generation' clusters is that 'age at migration' is either nonexistent for the second generation, since neither of the partners in the couple has migrated (they were born and raised in Belgium but have a foreign nationality) or low for the 'in-between generation' cluster. For the latter group, the (most recently migrated) European partner did move but at a very young age (on average seven years). The median level of education of this partner is moreover lower than that in the 'second generation' couple.

The level of education distinguishes the marriages linked to 'first-generation labour migration' and 'free movers'. The 'first-generation' cluster has overall the lowest median level of education for the (most recently migrated) European partner, that is lower secondary vocational education. This partner was around age 23 when he or she migrated to Belgium and married 3 years later. In the 'free movers' cluster, on the other hand, the (most recently migrated) European partner has the highest level of education with most commonly an education at post-secondary level. This longer phase of education might also explain the relatively high age at migration for this group (27 years on average). Many of these European 'free movers' have probably met their partner before migration, because marriage follows relatively quickly after migration. The 'free mover' couples also live further from the border than the other couples. Additional more in depth geographical analysis (not shown) indicates that a significant number of these couples reside in the Brussels Capital Region and in the surrounding communities.

The European bi-national couples linked to 'neighbourship' in turn live closest to the border (on average less than $3 \mathrm{~km}$ ). The (most recently migrated) European partner in these couples has moved to Belgium on average around the age of 21 and married 6 years later. So unlike the "free movers', many of them will have met their partners only after migration. Finally, there is a group of married couples for whom migration took place only at later age (on average around 48

Table 7. Characteristics of the (most recently migrated) European partner in the typology of European bi-national marriages (EU27).

\begin{tabular}{|c|c|c|c|c|c|}
\hline & $\begin{array}{c}\text { Age at } \\
\text { migration } \\
N^{*}=103383\end{array}$ & $\begin{array}{l}\text { Timing of marriage } \\
\text { after migration } \\
N^{*}=106323\end{array}$ & $\begin{array}{l}\text { Highest educational } \\
\text { level (median) } \\
\qquad N=161601\end{array}$ & $\begin{array}{l}\text { Distance to the nearest } \\
\text { border municipality } \\
(\mathrm{km}) \\
N=177084\end{array}$ & $\begin{array}{l}\begin{array}{l}\text { Percentage } \\
\text { of men }\end{array} \\
N=177084\end{array}$ \\
\hline $\begin{array}{l}\text { Second } \\
\text { generation }\end{array}$ & - & - & $\begin{array}{l}5 \text { (higher secondary } \\
\text { professional } \\
\text { education) }\end{array}$ & 21.1 & 51.6 \\
\hline $\begin{array}{l}\text { In-between } \\
\text { generation }\end{array}$ & 6.5 & 21.3 & 4 (lower secondary) & 24.3 & 56.0 \\
\hline $\begin{array}{l}\text { First-generation } \\
\text { labour } \\
\text { migration }\end{array}$ & 22.8 & 2.5 & $\begin{array}{l}3 \text { (lower secondary } \\
\text { technical } \\
\text { education) }\end{array}$ & 25.0 & 45.3 \\
\hline Free movers & 27.2 & 1.4 & $\begin{array}{l}10 \text { (higher } \\
\text { vocational non- } \\
\text { academic) }\end{array}$ & 29.6 & 42.8 \\
\hline Neighbourship & 20.5 & 5.9 & 4 (lower secondary) & 2.8 & 45.7 \\
\hline $\begin{array}{l}\text { Migration at later } \\
\text { age }\end{array}$ & 48.0 & -11.0 & $\begin{array}{l}6 \text { (higher secondary } \\
\text { technical } \\
\text { education) }\end{array}$ & 25.3 & 55.3 \\
\hline
\end{tabular}

*This variable is not relevant for partners of the second generation.

**When there is no native partner in the second generation couple (EUR-EUR), the most qualified partner is selected as partner of reference (N=605).

The criterion of most recently migrated partner is after all not applicable to this category.

Source: SEE 2001 - ADSEI, own adaptation. 
years). They got married on average 11 years before migrating to Belgium. The last column of Table 7 shows the gender specific distribution for each cluster (percentage of men). Among all clusters, we find a relative gender balance with two main exceptions. Women are overrepresented in the 'free mover' cluster. At the same time, we find a higher percentage of men among the European partners in the cluster linked to the 'in-between generation'.

Each of the clusters is comprised by a diversity of nationality groups except for one: those married linked to neighbourship (not shown). These latter couples consist of intermarried with French $(44 \%)$ and Dutch $(40 \%)$ partners and to a lesser extent with German (13\%) and Luxembourg (3\%) partners. The 'neighbours' nonetheless also dominate the other clusters. The nationality (at birth) of no less than $35 \%$ of the European partners in the 'second generation' and 'in-between generation' couples is from a neighbouring country and another $44 \%$ is Italian. Among those married and belonging to the clusters 'first-generation labour migrant', 'free movers' and 'migration at later age' more than half of all European partners are nationals of a neighbouring country. Otherwise, these clusters are again diverse. Finally, within the group of European bi-national couples, we also find nationals of new EU member states that did not yet belong to the EU at the time of the census in 2001. Of this group, a third was born in Belgium, 24\% can be considered 'free movers' and $20 \%$ as 'first-generation labour migrants' (not shown).

\section{DISCUSSION AND CONCLUSION}

Intermarriage is among the most studied topics in social sciences. Nevertheless, our knowledge on European bi-national marriages is still rather limited. Our study aims to overcome this gap in knowledge by describing prevalence, trends and background characteristics of European binational marriages in Belgium. The analyses show that despite the ongoing process of European integration and free mobility of EU citizens, European bi-national marriages are relatively rare in Belgium. Of all marriages contracted in 2010, only $6.4 \%$ were between two Europeans (EU27) of a different nationality. This is in line with our expectation based on the relative limited European mobility as indicated by for example Eurobarometer data. At the same time, the low percentage of intermarriages seems rather limited for a country that hosts the capital of the European Union.

The scarce literature on European intermarriages suggests that these marriages are on the rise in recent years. The abolishment of European borders, the realisation of free movement and the efforts to not only broaden but also deepen the European Union especially since the enlargement of the EU are all seen to contribute to this. However, our data do not support the expected increase of European bi-national marriages. The trends in European bi-national marriages in Belgium seem to be quite stable (or even slightly diminishing) over time (1989-2010). This contrasts the overall trends in bi-national marriages that are clearly increasing and are only on the decline in some of the most recent years. Apparently, the further extension of intra-European mobility so far has not resulted in an increasing number of bi-national European marriages. This does not imply that bi-national unions are nonexistent. It could very well be that those in bi-national unions do not marry but live in cohabiting unions that are also more vulnerable to dissolution. In addition, we have to take into account that because these bi-national marriages involve partners of two different nationalities, the marriages could just as well have taken place in the country of nationality of the non-Belgian partner. These marriages are then not reflected in the Belgian marriage registers. A full two country comparison would be necessary to capture the potential increase in bi-national unions across borders.

Our findings furthermore show that the propensity for Belgians to marry a partner from another European nationality is clearly related to the social and geographical distance. BelgianFrench and Belgian-Dutch marriages are most popular; Belgian-German marriages follow in fourth position. Furthermore, Luxembourgers and Germans are (together with the Brits) most probable to marry a Belgian partner when living in Belgium relative to other European foreigners according to our intermarriage index. The clear predominance of marriages with a partner from a neighbouring country within the group of European bi-national marriages reflects the importance of geographical and cultural 
proximity for the formation of these marriages and not at the least of language (this spatial homogamy has also been pointed out for the Netherlands in the work of Haandrikman et al., (2011)). Our findings suggest that perceived distances between groups, as thematised in the traditional intermarriage literature, may just as well form a major barrier to the formation of European intermarriages. However, this finding also points to the fact that contrary to suggestions made based on the Europeanisation process, the local marriage market remains very important.

Marriages with partners from traditional migrant groups, like Italians and Spaniards who have migrated to Belgium in the 1960s, are another group of most frequent European marriage partners in Belgium. Group boundaries between these groups and the majority in Belgian society might be blurring. However, the number of marriages among these groups has fallen due to the fact that in recent years there has been a sharp decline in nationals from these groups at marriageable ages. Migration from Southern European countries gradually reduced, and the first and second generations of these nationality groups are ageing. The third generation is born with Belgian nationality, and their marriages with a Belgian partner are therefore registered as uni-national and no longer included in the bi-national unions we are studying here. The extent to which new migrants from Southern EU countries, due to the economic crisis in Southern Europe, will result in new bi-national marriages remains to be seen. Their marriage behaviour can be perceived as a true experiment for the extent to which group boundaries have faded between these nationality groups and Belgians or whether the boundary blurring mainly applies to those of older migrant generations rather than to new arrivals.

Our data suggest that the propensity for marrying a partner from new European migrant groups, like those of Eastern Europe, among Belgians is low and also migrants from these origin groups seem (according to the intermarriage index) to be less inclined to engage in a European bi-national marriage compared to the other (more established or geographically closer) European origin groups. Whether this is related to the bridging of greater cultural distance, their presence as a new immigrant group in Belgium or their shorter history within the EU cannot be assessed with the data available to us. The EU membership for these countries might also have acted counterproductive for bi-national marriages and reduce attractiveness for these new EU citizens. Given the possibilities of free movement in the EU with entering the Union, the necessity of marriage, which previously was one of the few migration options to Belgium, clearly has declined.

In the last part of our analyses, we aimed to get more insight into the level of diversity among the group of European bi-national married by analysing individual and couple characteristics. Given the emphasis on European free movers in the literature on the European integration, we wanted to empirically explore the relevance of this group with regard to European bi-national marriages. Free movers are expected to take the lead in the creation of a European society (Gaspar, 2008, 2009). Their share in European bi-national marriages in 2001, however, was still relatively small $(13 \%)$ and comparable to that of married couples from neighbouring nationalities in border regions $(12 \%)$, and even smaller than that of the marriages of first-generation (European) migrant workers $(19 \%)$. The equally large share of bi-national marriages anchored in the border region confirms that despite the common assumption of a globalisation or at least Europeanisation of this market, a significant part of the marriage market is still locally determined. One should be aware that the data in this part of the analyses were based on the Belgian 2001 census. More recent census data are needed to test whether the characteristics of intermarried couple have changed and the share of for example free movers has increased over the past decade resulting in less local marriage choice.

Our analyses, furthermore, indicated that at least half of all European bi-national couples in the Belgian population at the time of the Census 2001 consist of two partners born and/or raised in Belgium, which points out that European migration has a much longer history than just that of European unification. Gaspar (2008) states that what individuals think, feel and do in different situations is largely the result of the country they were born and raised in, and according to her, the second generation should thus not be considered as European bi-national married. In line with theories on transnational family ties and their importance across generations (Baldassar et al., 2006; Kraler et al., 2012), we nevertheless claim that also these 
marriages among the second generation retain a strong European dimension through the social networks, cultural background and possibly also the language and mobility of the European partner. By a priori excluding this group, we miss out on an important dimension in the European marriage market, especially given the (growing) size of the second generation in many EU countries including Belgium.

The marriage register and census data used in our analysis are currently the most appropriate data to study trends and patterns in binational marriages. They do, nevertheless, have their merits and limitations. One is the lack of information on cohabitation. Given the increased relevance of this relationship form in most (Western) European countries, we might miss out on an important part of union formation, especially when there is reason to believe that cohabitation is more popular within bi-national than within uni-national couples (Blackwell and Lichter, 2000; Qian and Lichter, 2007). Further analyses on the census data - which partly allow studying cohabiting couples - show that more than onefifth of all European bi-national couples in 2001 are living together without being legally married. The share of European bi-national couples among all couples in 2001 nevertheless rises with less than $1 \%$ if we also include the cohabiting couples in the analysis. We may assume that cohabitation will become ever more important within recently formed European bi-national couples, so that future research needs to take these into account and explore them in more detail. Another limitation is that we define intermarriages based on nationality of partners. Although most nationality changes take place after marriage, changes before marriage can lead to either an overestimation of European binational marriages (when a European partner acquires Belgian nationality before marrying a partner of the previous European nationality) or, more common, an underestimation of these marriages (when a European partner acquires Belgian nationality before marrying a Belgian partner). A definition that transcends these theoretical and methodological problems is one that is based on country of origin (combining own country of birth and that of the parents), which also allows studying the second generation. Data containing this information for both partners are needed to better grasp these

Copyright (c) 2013 John Wiley \& Sons, Ltd. complex relations across generations. Finally, our analyses are just referring to Belgium. Getting more insight in processes of European partner choices would need a truly European approach. Further studies are needed to grasp the processes that are relevant for the partner choice of European citizens across national borders within the European Union.

\section{ACKNOWLEDGMENTS}

This contribution is part of the project 'Towards a European Society: Single Market, Bi-national Marriages, and Social Group Formation in Europe' (EUROMARR) financed by the 2009 ERCP programme of the European Science Foundation (project number 09-ERCP-044, FWO finance number G.0994.10N). We thank the reviewers for their valuable comments and suggestions for improvement. Special thanks to Michel Willems of Statistics Belgium (ADSEI) for providing us the necessary data from the Belgian marriage records. Furthermore, we gratefully acknowledge Didier Willaert for the data handling and processing assistance. Earlier versions of this article were presented at the 2011 International Conference of Europeanists (Barcelona) and the Sociology Day 2011 (Ghent).

\section{ENDNOTES}

(1) This percentage rises to $84 \%$ when we discard the nationality changes in 1992, when Europeans of the third generation in Belgian (mainly Italians) acquired Belgian nationality automatically and retrospectively due to changes in nationality law.

(2) We use $Z^{\prime}$ and not $Z$ because we do not dispose of the number of person years present in Belgium (taking into account the age of migration) for the total population according to nationality (Schoen, 1988). The original formula developed by Schoen (1988:214) to calculate intermarriage between two groups, can be described as follows:

$$
Z^{\prime}=\frac{C_{12} / M_{1}+C_{21} / F_{1}+C_{21} / M_{2}+C_{12} / F_{2}}{\left(C_{11}+C_{12}\right) / M_{1}+\left(C_{11}+C_{21}\right) / F_{1}+\left(C_{22}+C_{21}\right) / M_{2}+\left(C_{22}+C_{12}\right) / F_{2}}
$$

$\mathrm{Z}^{\prime}$ uses information on the population in the main marriage interval. $M_{i}$ in the formula refers to the male population in this interval in group $i . F_{j}$ refers to the female population in this interval in group $j$, and $C_{i j}$ is the number of marriages that are a combination of a 'male' partner from group $i$ and a 'female' partner from group $j$. 
(3) The original formula (as provided in the previous footnote (2) was adapted to consider intermarriages between partners of one specific European nationality (group 1) and partners of any other European nationality (group 2). It also needed to take into account marriages with partner of a non-European nationality. The modified formula is described as follows:

$Z^{\prime \prime}=\frac{C_{12} / M_{1}+C_{21} / F_{1}+C_{21} / M_{2}+C_{12} / F_{2}}{\left(C_{11}+C_{12}+C_{13}\right) / M_{1}+\left(C_{11}+C_{21}+C_{31}\right) / F_{1}+\left(C_{22}+C_{21} C_{23}\right) / M_{2}+\left(C_{22}+C_{12} C_{32}\right) / F_{2}}$

Group 3 contains all partners with a non-European identity. $Z^{\prime a}$ is equal to zero when all partners in group 1 marry within their own group. It is equal to one when all partners in a group marry with someone from another European nationality.

(4) A cluster solution with five clusters does not discriminate the very relevant group of 'free movers'. In the case of seven clusters, on the other hand, the group of European bi-national marriages of the inbetween generation is split into two only according to migration age.

(5) Belgium used the possibility to temporally suspend the free movement of workers in relation to nationals from 12 new member states. These transitional measures did not apply to nationals of Cyprus or Malta.

\section{REFERENCES}

Alba R. 2005. Bright vs. blurred boundaries: second generation assimilation and exclusion in France, Germany and the United States. Ethnic and racial studies 1: 20-49.

Bach M, Lahusen C, Vobruba G (eds.). 2006. Europe in Motion. Social Dynamics and Political Institutions in an Enlarging Europe. Edition Sigma: Berlin.

Baldassar L, Baldock CV, Wilding R. 2006. Families Caring Across Borders: Migration, Ageing and Transnational Caregiving. Palgrave MacMillan: London.

Barth F. 1969. Ethnic Groups and Boundaries. The Social Organization of Culture Difference. Scandinavian University Press: Oslo.

Behtoui A 2010. marriage pattern of immigrants in Sweden. Journal of Comparative Family Studies 41(3): 415-435.

Blackwell DL, Lichter DT. 2000. Mate selection among married and cohabiting couples. Journal of Family Issues 21: 275-302.

Blau PM. 1977. Inequality and Heterogeneity: A Primitive Theory of Social Structure. Free Press: New York.

Blau PM. 1994. Structural Contexts of Opportunities. The University of Chicago Press: Chicago.

Blau PM, Schwartz J. 1984. Crosscutting Social Circles. Academic Press: New York.

Boeri T, Hanson G, McCormick B (eds.). 2002. Immigration Policy and the Welfare System. A Report for the Fondazione Rodolfo Debenedetti in Association with the William Davidson Institute. Oxford University Press: New York.
Bonin H, Eichhorst W, Florman C, Hansen MO, Skiöld L, Stuhler J, Tatsiramos K, Thomasen H, Zimmerman KF. 2008. Geographic Mobility in the European Union: Optimising its Economic and Social Benefits. IZA: Bonn.

Braun M, Recchi E. 2008. Interethnic partnerships of Western Europeans: Between preferences and opportunities. Revista OBETS 1: 73-89.

Celikaksoy A, Nekby L, Rashid S. 2010. Assortative mating by ethnic background and education among individuals with an immigrant background in Sweden. Journal of Family Research 22: 65-88.

CGKR. 2006. Migratiestromen uit de nieuwe lidstaten van de Europese Unie naar België. Centrum voor Gelijkheid van Kansen en voor Racismebestrijding: Brussels.

CGKR. 2009. Migraties en migrantenpopulaties in België. Statistisch en demografisch verslag 2008. Centrum voor Gelijkheid van Kansen en voor Racismebestrijding: Brussels.

CGKR. 2012. Jaarverslag Migratie 2011. Centrum voor Gelijkheid van Kansen en voor Racismebestrijding: Brussels.

Chiswick B, Houseworth C. 2011. Ethnic intermarriage among immigrants: Human capital and assortative mating. Review of Economics of the Household 9: 149-180. DOI: 10.1007/s11150-010-9099-9.

Colpaert E (ed.). 2000. Gemengd verbonden. Kerkwerk Multicultureel Samenleven: Brussels.

Delanty G. 2005. What does it mean to be a 'European'? Innovation 18(1): 11-22.

Delhey J. 2004. European Social Integration. From Convergence of Countries to Transnational Relations between Peoples. Wissenchaftszentrum Berlin für Sozialforschung (WZB): Berlin.

Deschamps L. 2005. De internationalisering van de 'Vlaamse' huwelijksmarkt, een oriënterende schets. In: Huwelijksmigratie, een zaak van de overheid?, Caestecker F (ed.); Acco: Leuven/Voorburg; 37-46.

Devos V, Dams K. 2010. Lusobelgae. A Documentary on the Portuguese of Brussels. Office for Urban Reporting vzw: Brussels.

D'Haenens E. 1995. Kleurrijke liefde: Cultuurgemengde koppels vertellen. EPO: Berchem.

Diez Medrano J. 2008. Europeanization and the Emergence of a European Society. IBEI Working Papers 2008/12. Institut Barcelona d'Estudis Internacionals: Barcelona.

Dribe M, Lundh C. 2008. Intermarriage and immigrant integration in Sweden: an exploratory analysis. Acta Sociológica 51: 329-354.

Dribe M, Lundh C. 2012. Cultural dissimilarity and intermarriage. a longitudinal study of immigrants in Sweden 1990-2005. International Migration Review 45: 297-324.

European Commission. 2011. New Europeans. Special Eurobarometer 246. European Commission: Brussels. 
http:/ /ec.europa.eu/public_opinion/archives/ebs/ ebs_346_en.pdf, last accessed on 02/12/2011.

Eurostat. 2011. Statistics in Focus 34/2011. Eurostat: Luxembourg.

Favell A. 2001. Free Movers in Brussels. A Report on the Participation and Integration of European Professionals in the City. IPSOM: Brussels.

Favell A. 2003. Eurostars and Eurocities: towards a sociology of free moving professionals in Western Europe. CCIS Working Paper $N^{\circ} 71$. University of California: San Diego.

Favell A. 2008. Eurostars and Eurocities. Free Movement and Mobility in an Integrating Europe. Blackwell: Oxford.

FOD WASO. 2009. De immigratie in België: aantallen, stromen en arbeidsmarkt. Rapport 2009 aan het SOPEMI (OESO). FOD Werkgelegenheid, Arbeid en Sociaal Overleg: Brussels.

Gaspar S. 2008. Towards a Definition of European IntraMarriage as a New Social Phenomenon. CIES e-Working Paper $N^{\circ} 46 / 2008$. Centro de investigação e estudos de sociologia: Lisbon.

Gaspar S. 2009. Mixed Marriages between European Free Movers. CIES e-Working Paper No 65/2009. Centro de investigação e estudos de sociologia: Lisbon.

Gatti E. 2009. Een definitie van de expat: hoogopgeleide migranten in Brussel. Brussels Studies 28: 1-17.

Glowsky D. 2011. Globale Partnerwahl. Soziale Ungleichheit as Motor transnationaler Heiratentscheidungen. VS Verlag für Sozialwissenschaften: Wiesbaden.

Haandrikman K, van Wissen LJG, Harmsen CN. 2011. Explaining spatial homogamy; compositional, spatial and regional cultural determinants of regional patterns of spatial homogamy in the Netherlands. Applied Spatial Analysis and Policy 4(2): 75-93.

Hooghe L, Marks G. 2004. Does identity or economic rationality drive public opinion on European integration? Political Science and Politics 37(3): 415-420.

Huysseune M, Jans T. 2008. Brussels as the capital of a Europe of the regions? Regional Offices as European Policy Actors, Brussels Studies 16: 1-11.

Johnson B, Jacobson C. 2005. Contact in context: an examination of social settings on White's attitudes towards interracial marriage. Social Psychology Quarterly 68(4): 387-399.

Kalmijn M. 1998. Intermarriage and homogamy: causes, patterns, trends. Annual Review of Sociology 24: 395-421.

Kalmijn M, Van Tubergen F. 2010. A comparative perspective on intermarriage: explaining differences among national-origin groups in the United States. Demography 47(2): 459-479.

Khoo SE. 2004. Intermarriage in Australia. Patterns by ancestry, gender and generation. People and Place $\mathbf{1 2}$ (2): 35-44.

Koelet S, Schroedter J, Cortina C, de Valk HAG, de Busser C. (2012). Bi-national marriages between European citizens: from intermarriage to intramarriage? In: D-S Kim (Ed.); Cross-Border Marriage: Global Trends and Diversity. KIHASA: Seoul; 123-162.

Kraler A, Kofman E, Kohli M, Schmoll C (eds.) 2012. Gender, Generations and the Family in International Migration. Amsterdam University Press: IMISCOE research Amsterdam.

Kulczycki A, Lobo AP. 2002. Patterns, determinants, and implications of intermarriage among Arab Americans. Journal of Marriage and Family 64(1): 202-210.

Lanzieri G. 2011. A comparison of recent trends of international marriages and divorces in European countries. Presented at the IUSSP Seminar on Global Perspectives on Marriage and International Migration. The RitzCarlton, Seoul, October 20-21.

Lauth BJ. 2002. Cross-border marriages and the formation of transnational families: a case study of Greek-German couples in Athens. University of Oxford: Oxford.

Lievens J. 1998. Interethnic marriage: bringing in the context through multilevel modeling. European Journal of Population 14: 117-155.

Lievens J. 1999. Family-forming migration from Turkey and Morocco to Belgium: the demand for marriage partners from the countries of origin. International Migration Review 33(3): 717-744.

Lindenfeld J, Varro G. 2008. Language maintenance among 'fortunate immigrants': The French in the United States and Americans in France. International Journal of the Sociology of Language 2008(189): 115-131.

Lodewyckx I, Geets J, Timmerman C (eds.). 2006. Aspecten wan Marokkaanse huwelijksmigratie en Marokkaans familierecht. Steunpunt Gelijkekansenbeleid: Antwerp/Hasselt.

Muttarak R. 2009. Explaining Trends and Patterns of Immigrants' Partner Choice in Britain. European University Institute: Florence.

Niedomysl T, Östh J, van Ham M. 2010. The globalisation of marriage fields: the Swedish case. Ethnic and Migration Studies 36(7): 1119-1138.

O'Dowd L. 2003. The changing significance of European borders. In: New Borders for a Changing Europe. Cross-border Cooperation and Governance, Anderson J, O'Dowd L, Wilson TM (eds.); Frank Cass Publishers: London/Oregon; 13-37.

OECD. 2011. International Migration Outlook 2010. OECD Publications: Paris.

Offe C. 2000. The democratic welfare state in an integrating Europe. In: Democracy Beyond the State? The European Dilemma and the Emerging Global Order, Greven MT, Pauly LW (eds.) Rowman \& Littlefield Publishers, Inc.: Maryland/Oxford; 63-90.

Prioux F. 2004. Recent demographic developments in France. Population-E 59(5): 595-634.

Qian Z, Lichter DT. 2007. Social boundaries and marital assimilation: interpreting trends in racial and ethnic intermarriage. American Sociological Review 72(1): 68-94. 
Reniers G, Lievens J. 1997. Stereotypen in perspectief: De evolutie van enkele aspecten van het huwelijk bij de Turkse en Marokkaanse minderheden in België. Universiteit Gent, Vakgroep Bevolkingswetenschappen: Ghent.

Salt J, Almeida JC. 2006. International migration in Europe. Patterns and trends since the mid-1990s. Revue Européenne des Migrations Internationales 2(22): 155-175.

Sánchez-Domínguez M, de Valk HAG, Reher DS. 2011. Marriage strategies among immigrants in Spain. Revista Internacional de Sociología (1): 139-166.

Schoen R. 1988. Modeling Multigroup Populations. Plenum: New York.

Threlfall M. 2003. European social integration: harmonization, convergence and single social areas. Journal of European Social Policy 13(2): 121-139.

Timmerman C, Lodewyckx I, Wets J. 2009. Marriage at the intersection between tradition and globalization. Turkish marriage migration between Emirdag and Belgium from 1989 to present. The History of the Family 14: 232-244. DOI: $10.1016 / \mathrm{j}$. hisfam.2009.04.002.

van Tubergen F, Maas I. 2007. Ethnic intermarriage among immigrants in the Netherlands: an analysis of population data. Social Science Research 36: 1065-1086.

de Valk HAG, Liefbroer AC, Esveldt I, Henkens K. 2004. Family formation and cultural integration among migrants in the Netherlands. Genus 71(3-4): 9-36.

de Valk HAG, Huisman C, Noam K. 2011. Migration patterns and immigrant characteristics in northwestern Europe. NIDI: The Hague.

Vasileva K. 2009. Citizens of European Countries Account for the Majority of the Foreign Population in EU-27 in 2008. Statistics in Focus. Eurostat: Luxemburg.

Yalçin H, Lodewyckx I, Marynissen R, Van Caudenberg R. 2006. Verliefd, verloofd, gemigreerd. Een onderzoek naar Turkse huwelijksmigratie in Vlaanderen. Steunpunt Gelijkekansenbeleid: Antwerp/Hasselt. 